\title{
Decision Support System for Determination of Salaries Employees in Civil Service Police Unit Deli Serdang With Simple Additive weighting method (SAW)
}

\author{
Mifta Reza Yolanda ${ }^{1}$, R. Mahdalena Simanjorang ${ }^{2}$ \\ ${ }^{1.2}$ Informatics Engineering Study Program, STMIK Pelita Nusantara, Jl. St. Iskandar Muda No. \\ 1 Medan, North Sumatra, Indonesia 20154. \\ Email: miftarezayolanda@gmail.com
}

\begin{abstract}
This study examines how to design an application for the Deli Serdang Civil Service Police Unit in order to Facilitate the Process of Determining Salaries employee. With this application, it is hoped that it will make it Easier for the Office to Determine the determination of employee Salaries so that it is faster and more accurate. The SAW method certainly uses a more Appropriate assessment Because it is based on a criterion value of a predetermined preference weight. With the existence of accurate the data will be Able to minimize the time wasted and Be Able to use the system that is being designed. Data managed in the Office still uses Excel so that in its implementation the the data is still vulnerable to being scattered and the possibility of vulnerability to damage and loss of data.
\end{abstract}

Keywords:spk, saw, ppp.

\section{Introcuction}

The development of technology is currently growing and sophisticated. Especially these developments can fulfill in all aspects in life. The office should be able to follow some technological developments, especially with the problems and difficulties that have been encountered that can be solved more quickly and efficiently. Office of the Civil Service Police Unit Deli Serdang is engaged in the enforcement office which will produce and market order in the community. This office was established in 2001. Employees in the office consists of 148 employees. In the process of determining the salaries of employees at the office there are many problems. Thus the need for a Decision Support System for determining salaries. Decision Support Systems or Decision Support System is a part of a computer-based information system including a knowledge-based system or knowledge management is used to support decision-making in an organization. Can also be regarded as a computer system that processes data into information to make a decision on a specific semi-structured problems. Based on the description above then made application program in the form of Decision Support Systems, in order to facilitate the decision making, reduce decision-making errors, saving time, and increasing effectiveness. Decision Support System is a computer-based information system that is used in decision-making within an organization or company. In addition to using the application program in the form of Decision Support Systems, also using SAW method. SAW is the weighted summation method. The basic concept of the SAW method is to look for a weighted summation of rating performance on each alternative on all criteria.

\section{Theory}

\subsection{Understanding Decision Support System}

Decision Support Systems (DSS) are usually constructed to support a solution to a problem or an opportunity. Application of Decision Support System is used in decision making. Application of Decision Support System using CBIS (Computer Based Information Systems) are flexible, interactive, and can be adapted, developed to support specific management solutions to issues that are not structured.

With the above understanding, it can be explained that the Decision Support System is not a decisionmaking tool, but a system that can help decision-makers with information from the data that has been processed and is required to make a decision about an issue more quickly and accurately.

Kusrini (2017: 25) explains that the Decision Support System consists of several subsystems, namely: 
a) Data Management Subsystem enter the database that contains the data relevant to the circumstances that are managed by the software disebutsistem database management (DBMS / Database Mangement System). Subsystems can be interconnected data management with data warehousing company, a repository for enterprise data relevant to decision making.

b) Data Management Subsystem enter the database that contains the data relevant to the circumstances that are managed by the software disebutsistem database management (DBMS / Database Mangement System). Subsystems can be interconnected data management with data warehousing company, a repository for enterprise data relevant to decision making.

c) Data Management Subsystem enter the database that contains the data relevant to the circumstances that are managed by the software disebutsistem database management (DBMS / Database Mangement System). Subsystems can be interconnected data management with data warehousing company, a repository for enterprise data relevant to decision making.

d) The Knowledge-Based Management Subsystem supports all other subsystems or to act directly as an independent component and is optional.

\subsection{Simple Additive weighting method (SAW)}

According Kusumadewi (2006) in the journal Fajar Nugraha, Bayu Surarso, Beta Noranita entitled Evaluation Decision Support System Selection Procurement Asset winner with Simple Additive weighting method (SAW) Simple Additive weighting defines a weighted summation method. The basic concept is to find the SAW method of rating the performance of a weighted sum of each alternative on all criteria. SAW method requires a decision matrix normalization process $(\mathrm{X})$ to a scale comparable with the rating of the alternatives.

SAW method formula

$$
r_{i j}=\begin{gathered}
\frac{x_{i j}}{\operatorname{Max} x_{i j}} \text { Jikaj adalah attribut keuntungan benefit } \\
\frac{\operatorname{Min}_{i j}}{x_{i j}} \text { jika } j \text { adalah attribut biaya cost }
\end{gathered}
$$

Information:

rij $=$ normalization results

xij $=$ results have attributes in each criterion

Max xij $=$ The results of each criterion

Min $x i j=$ The smallest results of each criterion

benefit $=$ if the result is the best site

cost $=$ if the smallest is the best result

Where rij as normalized performance rating of alternatives on attribute $\mathrm{Ai} \mathrm{Cj} ; \mathrm{i}=1,2, \ldots, \mathrm{m}$ and $\mathrm{j}=1,2$, $\ldots, n$. the result of preference for each alternative (Vi).

$$
V_{i}=W_{j=1} r_{i j}
$$

Information:

$\mathrm{Vi} \quad=$ Ranking for each alternative

wj $\quad=$ The result of the weight of each criterion

rij = results normalized performance rating

Vi larger value indicates that the alternative $\mathrm{Ai}$ is selected.

The steps of determining a decision to increase employee salaries using SAWadalah as follows:

a) Specifies criteria for determining yangakandijadikan reference in decision making.

b) Providing value to the alternative on any predetermined criteria.

c) The rating determines the suitability of each alternative on each criterion.

d) Give the weight values obtained padanilai crips. 
e) Denganmenghitung matrix normalized to the value of normalized performance rating.

f) Process perangkingan each alternative by multiplying the weight value with the value of normalized performance rating.

\section{Research methods}

The framework will be conducted by researchers in an effort to find the data and information that will assist in making the study are as follows.

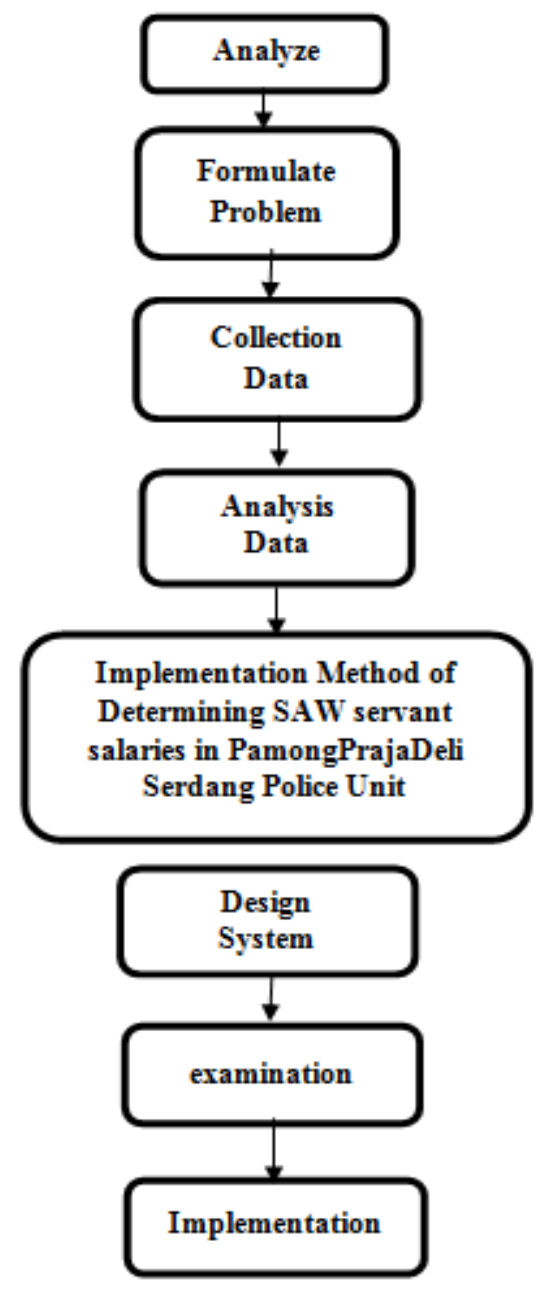

Fig. 1. Framework Research

\section{Analysis}

\subsection{Criteria}

In a study with Simple Additive Weightingini methods are the criteria needed to determine the increase in salaries. The criteria are as follows:

\begin{tabular}{|c|c|}
\hline $\begin{array}{c}\text { Criterion } \\
\text { ID }\end{array}$ & Criteria \\
\hline K1 & Education \\
\hline $\mathrm{K} 2$ & Group / Rank \\
\hline $\mathrm{K} 3$ & Competence \\
\hline $\mathrm{K} 4$ & Length of working \\
\hline
\end{tabular}




\subsection{Weight}

Of each criterion will be determined weight-weights to the criteria for having a different number. Below is a table of weights to each criterion.

\begin{tabular}{|c|c|c|c|}
\hline \multicolumn{4}{|c|}{$\begin{array}{l}\text { Table } 2 . \\
\text { Weight }\end{array}$} \\
\hline Criteria & Information & $\begin{array}{l}\text { The set of criteria } \\
\text { sub Criteria }\end{array}$ & Weight \\
\hline K1 & Education & $\mathrm{S} 3$ & 5 \\
\hline & & $\mathrm{S} 2$ & 4 \\
\hline & & $\mathrm{S} 1$ & 3 \\
\hline & & D3 & 2 \\
\hline & & High School & 1 \\
\hline $\mathrm{K} 2$ & Group / Rank & IV & 4 \\
\hline & & III & 3 \\
\hline & & II & 2 \\
\hline & & I & 1 \\
\hline $\mathrm{K} 3$ & Competence & Very good & 5 \\
\hline & & Well & 4 \\
\hline & & Pretty good & 3 \\
\hline & & Not good & 2 \\
\hline & & $\mathrm{Bad}$ & 1 \\
\hline K4 & Length of working & 10 years & 5 \\
\hline & & 7.5 to 10 Years & 4 \\
\hline & & 5 to 7.5 Years & 3 \\
\hline & & 2.5 to 5 Years & 2 \\
\hline & & $1-2.5$ Years & 1 \\
\hline
\end{tabular}

\subsection{Alternative Value Data}

Table 3.

Alternative Value Data

\begin{tabular}{|c|c|c|c|c|c|}
\hline \multirow[b]{2}{*}{ Code } & \multirow[b]{2}{*}{ Alternative } & \multicolumn{4}{|c|}{ Criteria } \\
\hline & & K1 & $\mathbf{K} 2$ & K3 & K4 \\
\hline A1 & Citra Efendy Capah & $\mathrm{S} 2$ & IIIC & Pretty good & 7.5 to 10 Years \\
\hline $\mathrm{A} 2$ & Ahmad Efendi Siregar & D3 & IIB & Well & 5 to 7.5 Years \\
\hline $\mathrm{A} 3$ & Suryadi Aritonang & S1 & IIIA & $\mathrm{Bad}$ & 5 to 7.5 Years \\
\hline A4 & Andika Putra & S1 & IID & Pretty good & $2.5-5$ tahun \\
\hline A5 & Nining Suryani & $\mathrm{S} 2$ & IIIB & Well & 2.5 - 5tahun \\
\hline
\end{tabular}

4.4 Rating table alternative matches

Table 4.

Rating suitability of alternative

\begin{tabular}{ccccc}
\hline \multirow{2}{*}{ Alternative } & \multicolumn{4}{c}{ Criteria } \\
\cline { 2 - 5 } & K1 & K2 & K3 & K4 \\
\hline A1 & 4 & 3 & 3 & 4 \\
A2 & 2 & 2 & 4 & 3 \\
A3 & 3 & 3 & 1 & 3 \\
A4 & 3 & 2 & 3 & 2 \\
A5 & 4 & 3 & 4 & 2 \\
\hline
\end{tabular}


4.5 The decision matrix $x$

$X=\left\{\begin{array}{llll}4 & 3 & 3 & 4 \\ 2 & 2 & 4 & 3 \\ 3 & 3 & 1 & 3 \\ 3 & 2 & 3 & 2 \\ 4 & 3 & 4 & 2\end{array}\right\}$

4.6 Criteria for Education (K1).

$$
\begin{aligned}
& r 1,1=\frac{4}{\operatorname{Max}\{4,2,3,3,4\}}=\frac{4}{4}=1 \\
& r 2,1=\frac{2}{\operatorname{Max}\{4,2,3,3,4\}}=\frac{2}{4}=0.5 \\
& r 3,1=\frac{3}{\operatorname{Max}\{4,2,3,3,4\}}=\frac{3}{4}=0.75 \\
& r 4,1=\frac{3}{\operatorname{Max}\{4,2,3,3,4\}}=\frac{3}{4}=0.75 \\
& r 5,1=\frac{4}{\operatorname{Max}\{4,2,3,3,4\}}=\frac{4}{4}=1
\end{aligned}
$$

\subsection{The payoff matrix normalization}

$$
X=\left\{\begin{array}{llll}
1 & 1 & 0.75 & 1 \\
0.5 & 0.6 & 1 & 0.75 \\
0.75 & 1 & 0: 25 & 0.75 \\
0.75 & 0.6 & 0.75 & 0.5 \\
1 & 1 & 1 & 0.5
\end{array}\right\}
$$

4.8 The rating value calculation

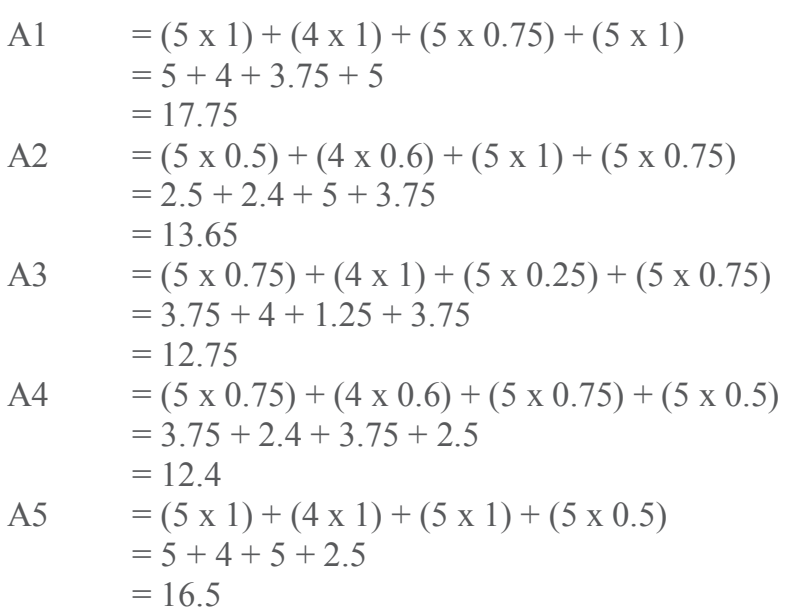

4.9 Perangkingan results table

Table 5.

Results perangkingan

\begin{tabular}{lcc}
\hline Code & Alternative & $\begin{array}{c}\text { Score } \\
(\mathbf{\%})\end{array}$ \\
\hline A1 & Citra Efendy Capah & 17.75 \\
\hline
\end{tabular}




\subsection{System planning}

\begin{tabular}{lll}
\hline Code & \multicolumn{1}{c}{ Alternative } & \multicolumn{1}{c}{$\begin{array}{c}\text { Score } \\
(\mathbf{\%})\end{array}$} \\
\hline A2 & Ahmad Efendi Siregar & 13.65 \\
A3 & Suryadi Aritonang & 12.75 \\
A4 & Putra Andika & 12.4 \\
A5 & Nining Suryani & 16.5 \\
\hline
\end{tabular}

a) Use Case Diagram

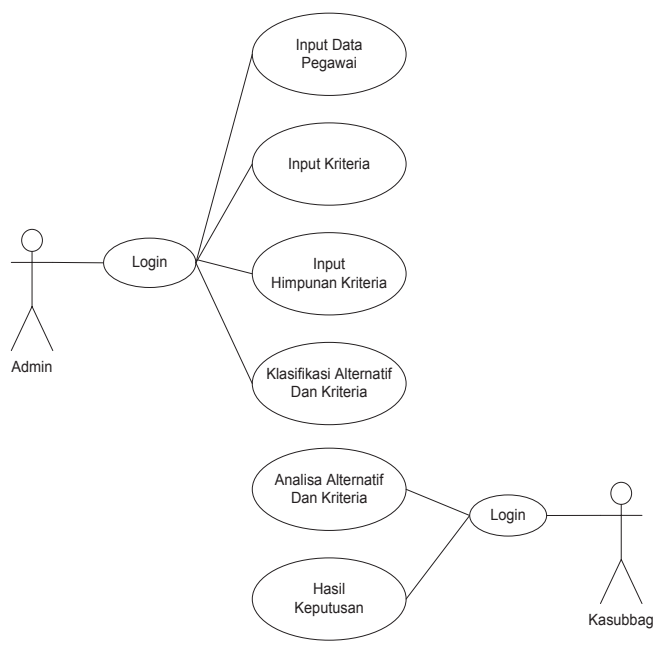

Fig.2 Use Case Diagram

\section{Conclusion}

Based on the results of the design and manufacture of Decision Support System Determination servant salaries, the authors can conclude them are ::

1. The problems that occur in connection with the determination of employee salaries can be solved by applying the SAW method.

2. By applying the SAW method for the determination of employee salaries in the Civil Service Police Unit Deli Serdang can be adapted to the criteria and using weights that can be used by the algorithm.

3. The system used a programming language built with Visual Studio 2010 and Microsoft Access 2016 for determination of salary for employees in the Civil Service Police Unit Deli Serdang quickly and accurately.

\section{Reference}

[1] Kusrini, Konsep Dan Aplikasi Sistem Pendukung Keputusan, 2017

[2] Jogiyanto, Analisis Dan Desain, 2018

[3] Julius Hermawan, Perancangan Sistem Pendukung Pengambilan Keputusan Untuk Penerimaan Beasiswa dengan Metode SAW, Jurnal Teknologi Informasi DINAMIKVol.16, No.2, Juli $2011: 160-170$

[4] Raymond Mc Leod, Jr, Perancangan Sistem Pendukung Pengambilan Keputusan Untuk Peneriman Beasiswa dengan Metode SAW, Jurnal Teknologi Informasi DINAMIK Vol.16, No.2, Juli 2011 : 171-176

[5] Kusumadewi, Sistem Pendukung Keputusan Evaluasi Pemilihan Pemenang Pengadaan Aset dengan Metode SAW, Jurnal Sistem Informasi Basis 02(2012)

[6] Dicky Nofriansyah, Konsep Data Mining VS Sistem Pendukung Keputusan, Mei 2015

[7] Windu Gata Grace, Pemodelan UML Sistem Informasi Monitoring Penjualan dan Stok Barang, Jurnal Khatulistiwa Informatika, Vol.IV, No.2 Desember 2016

[8] Ade Handini, Pemodelan UML Sistem Informasi Monitoring Penjualan dan Stok Barang, Jurnal Khatulistiwa Informatika, Vol.IV, No.2 Desember 2016

[9] Fajar Rahadian, Sistem Pengelolaan Database Siswa Menggunakan Pemrograman Visual Studio.Net, Jurnal Pendidikan Dompet Dhuafa edisi I/2011

[10] Turban, Konsep Dan Aplikasi Sistem Pendukung Keputusan, 2017 